\title{
Subchronic treatment with antiepileptic drugs modifies pentylenetetrazol-induced seizures in mice: Its correlation with benzodiazepine receptor binding
}

\author{
Luisa Rocha \\ Pharmacobiology Department, Center \\ for Research and Advanced Studies, \\ Calz, Tenorios, México
}

\begin{abstract}
Experiments using male CD1 mice were carried out to investigate the effects of subchronic (daily administration for 8 days) pretreatments with drugs enhancing GABAergic transmission (diazepam, $10 \mathrm{mg} / \mathrm{kg}$, ip; gabapentin, $100 \mathrm{mg} / \mathrm{kg}$, po; or vigabatrin, $500 \mathrm{mg} / \mathrm{kg}$, po) on pentylenetetrazol (PTZ)-induced seizures, $24 \mathrm{~h}$ after the last injection. Subchronic administration of diazepam reduced latencies to clonus, tonic extension and death induced by PTZ. Subchronic vigabatrin produced enhanced latency to the first clonus but faster occurrence of tonic extension and death induced by PTZ. Subchronic gabapentin did not modify PTZ-induced seizures. Autoradiography experiments revealed reduced benzodiazepine receptor binding in several brain areas after subchronic treatment with diazepam or gabapentin, whereas subchronic vigabatrin did not induce significant receptor changes. The present results indicate differential effects induced by the subchronic administration of diazepam, vigabatrin, and gabapentin on the susceptibility to PTZ-induced seizures, benzodiazepine receptor binding, or both.
\end{abstract}

Keywords: diazepam, gabapentin, vigabatrin, pentylenetetrazol, benzodiazepine receptors

\section{Introduction}

The increasing brain GABA (gamma-amino butyric acid) content and administration of centrally active GABA-mimetic agents have been used as an effective therapeutic approach for the treatment of epilepsy (Olsen and Avoli 1997). However, it has also been suggested that the use of drugs that continually alter synaptic transmission does not represent the best strategy to control seizure expression (Gale 1992). Prolonged administration of drugs enhancing GABA action can lead to reduced GABAergic function (Gyenes et al 1988) and alterations in $\mathrm{GABA}_{\mathrm{A}}$ receptors (Calkin and Barnes 1994; Yu and Ticku 1995) as well as tolerance and dependence, especially to sedative and anticonvulsant effects of drugs such as benzodiazepines (BDZ) (Braestrup et al 1979).

The increase of GABAergic transmission can induce excitatory effects (Gale 1992). Chronic administration of BDZ can produce decreased sensitivity to GABA (Gallager et al 1984) and reduced ability of this amino acid to enhance BDZ binding (Brett and Pratt 1995). Indeed, withdrawal symptoms or spontaneous seizures have been reported to occur in nonepileptic BDZ abusers upon drug discontinuation (Lukas and Griffith 1984).

The present study was designed to determine the effects of subchronic pretreatment with drugs enhancing GABAergic transmission on pentylenetetrazol (PTZ)-induced seizures and their correlation with BDZ receptor binding. We used vigabatrin, gabapentin, and diazepam because these are antiepileptic compounds 
activating the GABAergic system. Vigabatrin is a GABA structural analogue, which irreversibly blocks GABA transaminase (GABA-T), the enzyme responsible of GABA degradation (Lippert et al 1977; Schechter et al 1979). The mechanisms of action of gabapentin, an analogue of GABA (Suman-Chauhan et al 1993), appear to be a complex synergy between increased GABA synthesis and function (Taylor et al 1998), non-NMDA receptor antagonism and binding to the $\alpha 2 \delta$-subunit of voltage dependent calcium channels. The latter action inhibits the release of excitatory neurotransmitters (Bennet and Simpson 2004). Diazepam, as a $\mathrm{BDZ}$ agonist, increases the channel opening frequency in presence of GABA increasing the effects of this amino acid (Haefely et al 1995). Autoradiography studies using $\left[{ }^{3} \mathrm{H}\right]$ flunitrazepam were carried out to evaluate BDZ receptor binding in specific brain areas of mice treated subchronically with these antiepileptic drugs.

\section{Material and methods}

\section{Animals}

The experimental subjects were adult male CD-1 mice, weighing $25-30 \mathrm{~g}$ at the beginning of the experiments. Animals were housed in groups of 5- 6 per cage $(24 \times 17 \times 12 \mathrm{~cm})$ under controlled environmental conditions $\left(22 \pm 1^{\circ} \mathrm{C}\right.$; 12 ; 12-h light-dark cycle, lighting at 8:00 h; food and water ad libitum). Experimental procedures were conducted according to the Mexican Official Standard NOM-062-ZOO-1999 and the Ethical Committee of the Center for Research and Advanced Studies (Mexico, Project 222/04).

\section{Evaluation of PTZ-induced seizures}

Mice received a daily administration of saline $(0.1 \mathrm{ml} / 10 \mathrm{~g}$, per oral [po] or intraperitoneal [ip]) for 1 week. This procedure allows the animals to habituate to manipulation, avoiding downregulation of BDZ binding induced by acute handling (Andrews et al 1992). Thereafter, they were daily treated with vigabatrin $(500 \mathrm{mg} / \mathrm{kg}$ po, $\mathrm{n}=10)$, gabapentin $(100 \mathrm{mg} / \mathrm{kg}$ po, $\mathrm{n}=10)$, or diazepm $(10 \mathrm{mg} / \mathrm{kg}$ ip, $\mathrm{n}=10)$ for 8 days. Immediately after each drug administration, animals were kept in individual cages for 30 min for behavioral evaluation. Preliminary experiments from our group indicated that a single administration of diazepam, gabapentin, or vigabatrin, at the doses and routes described above, was able to reduce PTZ-induced seizures and Fos expression in the mouse brain. For the present study, we chose the oral route for gabapentin and vigabatrin administration because it is how these drugs are used in patients. Indeed, vigabatrin exerts similar anticonvulsant potency at oral and ip administration (Loscher and Frey 1987). A solution of PTZ (Sigma Aldrich Ltd., St. Louis, MO, USA) freshly prepared was applied $(90 \mathrm{mg} / \mathrm{kg}$, ip) $24 \mathrm{~h}$ after the last drug administration. Latencies to the first clonic seizure, tonic extension, and convulsion-induced death were evaluated during $30 \mathrm{~min}$. The criterion of death was considered when animals spent 1 min or more with breathing and heart arrest. For each experimental drug, one control group $(\mathrm{n}=10)$ was monitored in parallel. Control animals were manipulated as described above, except that they received daily saline administration instead of antiepileptic drugs. Diazepam was dissolved in vehicle $(0.5 \%$ Tween 80 and saline), whereas gabapentin, vigabatrin, and PTZ were dissolved in saline.

\section{Evaluation of $\left[{ }^{3} \mathrm{H}\right]$ flunitrazepam binding}

After daily injection of saline $(0.1 \mathrm{ml} / 10 \mathrm{~g}$, po or ip) for 1 week, mice received daily administration with vigabatrin, gabapentin, or diazepam for 8 days, at the doses and routes described above ( $n=10$ per drug). For each drug, a control group $(\mathrm{n}=10)$ was monitored in parallel, in which animals received saline instead of antiepileptic drugs. Mice were sacrificed by decapitation $24 \mathrm{~h}$ after the last administration and their brains were quickly removed, frozen in pulverized dry ice and stored at $-70{ }^{\circ} \mathrm{C}$. Frozen coronal sections of $20 \mu \mathrm{m}$ were cut in a cryostat, thaw-mounted on gelatin-coated slides, and stored at $-70{ }^{\circ} \mathrm{C}$ until the day of incubation.

Tris-HCl buffer (170 mM, pH 7.4) was used. Initially, brain sections were prewashed for $30 \mathrm{~min}$ at $25^{\circ} \mathrm{C}$. Then, brain sections were incubated during $45 \mathrm{~min}$ at $4{ }^{\circ} \mathrm{C}$ in a $2 \mathrm{nM}\left[{ }^{3} \mathrm{H}\right]$ flunitrazepam solution $(88 \mathrm{Ci} / \mathrm{mmol})$, in absence or presence of $1 \mu \mathrm{M}$ of chlordiazepoxide. Binding obtained in presence of chlordiazepoxide was considered non-specific. Incubation was completed with 2 consecutive washes ( $1 \mathrm{~min}$ each) and a distilled water rinse $(2 \mathrm{~s})$ at $4{ }^{\circ} \mathrm{C}$. The sections were then quickly dried under a gentle stream of cold air.

Slides were arrayed in X-ray cassettes with tritium standards (Amersham Biosciences, Piscataway, NJ, USA) and apposed to tritium-sensitive film (Amersham Ultrafilm) for 3 weeks at room temperature. Films were developed using standard Kodak D11 and fixer. Optical densities were determined using a video-computer enhancement program (JAVA Jandel Video Analysis Software; Jandel Scientific, Corte. Madera, CA, USA). Brain regions were localized by reference to the mouse brain atlas of William and colleagues (1999). For each structure, 10 optical density readings were taken from at least 5 sections and they were averaged. The optical density readings of the standards were used to determine tissue radioactivity values $\left(\mathrm{dpm} / \mathrm{mm}^{2}\right)$ for the accompanying 

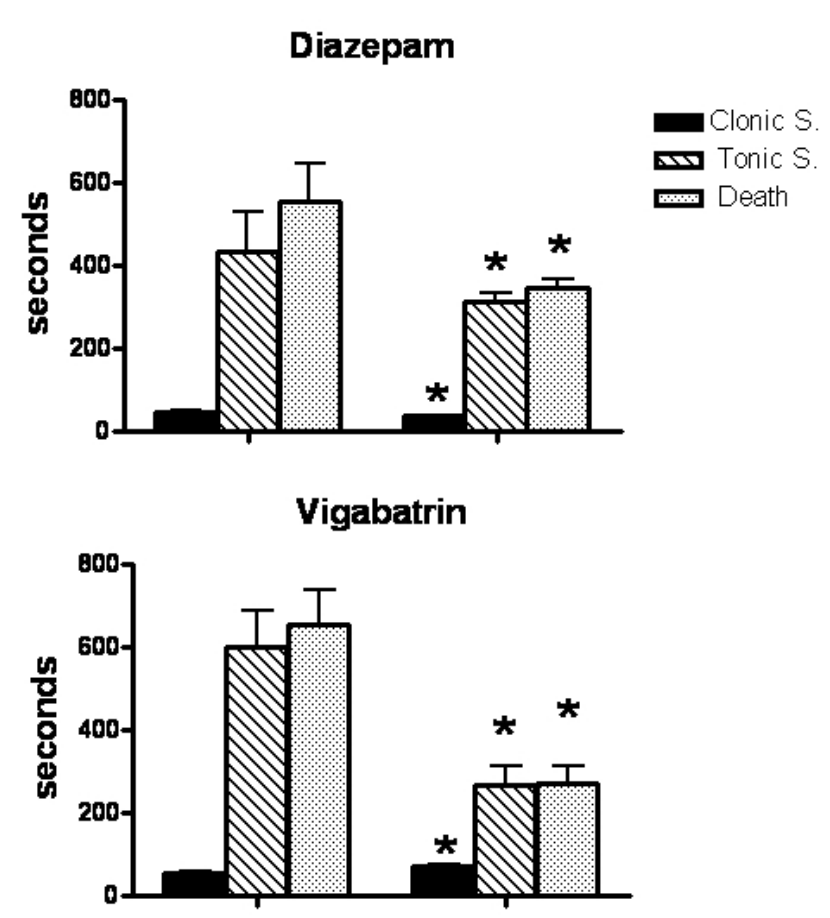

Gabapentin

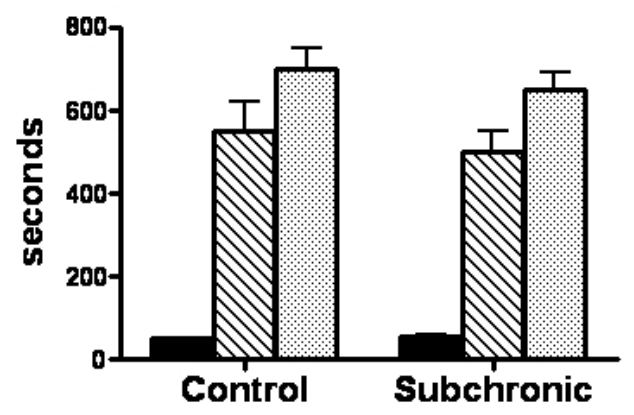

Figure I Effects of subchronic administration with diazepam (upper panel), vigabatrin (medium panel) and gabapentin (lower panel) on PTZ-induced convulsions. Results show the latency in seconds from the injection of PTZ ( $90 \mathrm{mg} / \mathrm{kg}$ ip) to first clonus, tonic extension and death.

Note: ${ }^{*} p<0.05$ when compared with control group.

tissue sections. Then, $\mathrm{dpm} / \mathrm{mm}^{2}$ values were converted to fmol/mg protein by dividing dpm by the specific activity of $\left[{ }^{3} \mathrm{H}\right]$ flunitrazepam $(88 \mathrm{Ci} / \mathrm{mmol})$ by 2.22 . The value 2.22 represents the conversion factor from $\mathrm{Ci}$ to $\mathrm{dpm}$.

$\left[{ }^{3} \mathrm{H}\right]$ flunitrazepam binding was analyzed in the following structures: motor, sensorimotor, and cingulate cortices; caudate putamen, nucleus accumbens, dentate gyrus, and CA1-3 fields of hippocampus; medial, and basolateral amygdala nuclei; complete thalamus and hypothalamus.

\section{Statistical analysis}

The values obtained from PTZ-induced seizures and receptor binding were examined statistically by Student's $t$ tests.

\section{Results}

Saline group

All control animals (100\%) pretreated with saline presented clonic seizures, and tonic extension after PTZ administration. The incidence of death was from $60 \%$ to $80 \%$. Latencies (mean \pm SD) for these PTZ-induced changes were as follows: clonic seizures, $50 \pm 4 \mathrm{~s}$; tonic extension, $527 \pm 86 \mathrm{~s}$; death, $636 \pm 74 \mathrm{~s}$ (Figure 1). Concerning BDZ binding, $\left[{ }^{3} \mathrm{H}\right]$ flunitrazepam binding was robust throughout the following evaluated brain areas: motor, sensorimotor, and cingulate cortices, dentate gyrus, CA1-3 fields of hippocampus, medial, and basolateral amygdala nuclei. $\left[{ }^{3} \mathrm{H}\right]$ flunitrazepam binding was mild to moderate at the level of caudate putamen, nucleus acumbens, thalamus and hypothalamus (Tables 1-3).

\section{Effects of subchronic administration with diazepam}

Mice pretreated subchronically with diazepam showed reduced latency to the first PTZ-induced clonus $(21 \%$, $\mathrm{p}<0.05)$, tonic extension $(27 \%, \mathrm{p}<0.05)$ and death $(37 \%$, $\mathrm{p}<0.05$ ) (Figure 1). Mortality rate was similar to that found in the control group (80\%).

Subchronic administration with diazepam induced a significant decrease of $\left[{ }^{3} \mathrm{H}\right]$ flunitrazepam binding in motor $(25 \%, \mathrm{p}<0.05)$, sensorimotor $(27 \%$, $\mathrm{p}<0.05)$ and cingulate $(38 \%, \mathrm{p}<0.05)$ cortices, dentate gyrus $(33 \%, \mathrm{p}<0.05)$, and CA $1-3$ fields of hippocampus $(34 \%, \mathrm{p}<0.05)$, medial $(41 \%, \mathrm{p}<0.05)$ and basolateral $(40 \%, \mathrm{p}<0.05)$ amygdala nuclei, and hypothalamus $(35 \%$, $\mathrm{p}<0.05)$ (Table 1).

Table I [ $\left.{ }^{3} \mathrm{H}\right]$ Flunitrazepam binding ( $\mathrm{fmol} / \mathrm{mg}$ of protein) in brain areas of mice treated with subchronic administration of saline and diazepam (10 mg/kg ip)

\begin{tabular}{lll}
\hline Brain area & Saline & Diazepam \\
\hline Motor cortex & $524.7 \pm 27.5$ & $382.6 \pm 61.0^{*}$ \\
Sensorimotor cortex & $503.4 \pm 35.2$ & $367.6 \pm 62.4^{*}$ \\
Cingulate cortex & $542.1 \pm 30.1$ & $334.4 \pm 50.0^{*}$ \\
Caudate putamen & $199.2 \pm 40.0$ & $143.7 \pm 8.4$ \\
Nucleus accumbens & $253.8 \pm 38.1$ & $210.9 \pm 34.9$ \\
CAI-CA3 fields & $435.7 \pm 57.1$ & $286.1 \pm 47.7^{*}$ \\
Dentate gyrus & $564.3 \pm 62.1$ & $378.5 \pm 69.4^{*}$ \\
Medial amygdala & $552.7 \pm 50.2$ & $322.8 \pm 56.6^{*}$ \\
Basolateral amygdala & $466.3 \pm 60.6$ & $276.3 \pm 56.8^{*}$ \\
Thalamus & $290.6 \pm 37.7$ & $206.8 \pm 34.7$ \\
Hypothalamus & $431.5 \pm 53.4$ & $280.3 \pm 57.3^{*}$ \\
\hline
\end{tabular}

Notes: Each value represents the mean \pm standard error; ${ }^{*} \mathrm{p}<0.05$ compared with the saline group. 
Table $2\left[{ }^{3} \mathrm{H}\right]$ Flunitrazepam binding ( $\mathrm{fmol} / \mathrm{mg}$ of protein) in brain areas of mice treated with subchronic administration of saline and vigabatrin $(500 \mathrm{mg} / \mathrm{kg} \mathrm{po})$

\begin{tabular}{lll}
\hline Brain area & Saline & Vigabatrin \\
\hline Motor cortex & $439.7 \pm 52.4$ & $398.9 \pm 33.8$ \\
Sensorimotor cortex & $360.3 \pm 50.6$ & $368.9 \pm 38.3$ \\
Cingulate cortex & $408.5 \pm 51.5$ & $386.6 \pm 33.6$ \\
Caudate putamen & $180.4 \pm 21.9$ & $147.4 \pm 13.6$ \\
Nucleus accumbens & $190.7 \pm 26.6$ & $168.6 \pm 14.6$ \\
CAI-CA3 fields & $292.1 \pm 38.7$ & $272.6 \pm 23.0$ \\
Dentate gyrus & $365.8 \pm 43.2$ & $351.5 \pm 30.8$ \\
Medial amygdala & $354.5 \pm 46.2$ & $379.8 \pm 31.8$ \\
Basolateral amygdala & $288.5 \pm 29.4$ & $295.1 \pm 34.0$ \\
Thalamus & $245.1 \pm 31.5$ & $277.8 \pm 26.9$ \\
Hypothalamus & $296.9 \pm 36.4$ & $292.6 \pm 24.7$ \\
\hline
\end{tabular}

Notes: Each value represents the mean \pm standard error.

\section{Effects of subchronic administration with vigabatrin}

Animals pretreated subchronically with vigabatrin presented enhanced latency to the first clonus $(32 \%, \mathrm{p}<0.05)$, but shorter latencies for tonic extension $(55 \%, \mathrm{p}<0.05)$ and death $(58 \%, \mathrm{p}<0.05)$ (Figure 1). Mortality rate was not significantly modified $(60 \%)$ when compared with control group $(70 \%)$.

Subchronic administration with vigabatrin tended to decrease $\left[{ }^{3} \mathrm{H}\right]$ flunitrazepam binding in motor $(10 \%)$ and cingulate $(6 \%)$ cortices; caudate putamen $(18 \%)$ and nucleus accumbens (11\%) (Table 2).

\section{Effects of subchronic administration with gabapentin}

Mice treated subchronically with gabapentin did not show significant changes in latency to the different components of PTZ-induced convulsions (Figure 1). However, their

Table $3\left[{ }^{3} \mathrm{H}\right]$ Flunitrazepam binding ( $\mathrm{fmol} / \mathrm{mg}$ of protein) in brain areas of mice treated with subchronic administration of saline and gabapentin (100 mg/kg po)

\begin{tabular}{lll}
\hline Brain area & Saline & Gabapentin \\
\hline Motor cortex & $505.5 \pm 23.2$ & $401.8 \pm 30.4^{*}$ \\
Sensorimotor cortex & $503.1 \pm 29.4$ & $329.1 \pm 37.7^{*}$ \\
Cingulate cortex & $501.5 \pm 53.2$ & $397.2 \pm 33.0^{*}$ \\
Caudate putamen & $190.4 \pm 21.3$ & $173.9 \pm 28.4$ \\
Nucleus accumbens & $296.5 \pm 28.3$ & $218.9 \pm 27.9$ \\
CAI-CA3 fields & $480.7 \pm 12.8$ & $315.3 \pm 33.5^{*}$ \\
Dentate gyrus & $535.7 \pm 18.4$ & $417.7 \pm 29.8^{*}$ \\
Medial amygdala & $463.9 \pm 50.7$ & $338.0 \pm 40.7^{*}$ \\
Basolateral amygdala & $458.8 \pm 15.7$ & $306.3 \pm 32.67^{*}$ \\
Thalamus & $315.5 \pm 55.2$ & $172.6 \pm 32.3^{*}$ \\
Hypothalamus & $389.1 \pm 56.3$ & $238.9 \pm 49.6$ \\
\hline
\end{tabular}

Notes: Each value represents the mean \pm standard error; ${ }^{*} p<0.05$ compared with the saline group. mortality rate was lower (40\%) when compared with control animals $(60 \%)$.

Subchronic administration with gabapentin reduced $\left[{ }^{3} \mathrm{H}\right]$ flunitrazepam binding in the motor $(20 \%, \mathrm{p}<0.05)$, sensorimotor $(34 \%, \mathrm{p}<0.05)$ and cingulate $(20 \%, \mathrm{p}<0.05)$ cortices; dentate gyrus $(22 \%, \mathrm{p}<0.05)$ and CA1-CA3 fields of hippocampus $(34 \%, \mathrm{p}<0.05)$, medial $(27 \%, \mathrm{p}<0.05)$ and basolateral $(33 \%, \mathrm{p}<0.05)$ amygdala nuclei, thalamus $(45 \%$, $\mathrm{p}<0.05)$ and hypothalamus $(38 \%, \mathrm{p}<0.05)$ (Table 3$)$.

\section{Discussion}

There is growing awareness that antiepileptic drugs can sometimes worsen epileptic disorders (Perucca et al 1998) by disrupting the equilibrium between excitatory and inhibitory circuits (Loiseau 1998). In the present study, we found that mice pretreated subchronically with antiepileptic drugs enhancing GABAergic neurotransmission showed an augmented susceptibility to PTZ-induced seizures, reduced $\mathrm{BDZ}$ receptor binding, or both. These effects may be associated with a withdrawal-like syndrome as consequence of the sudden cessation of antiepileptic drugs.

PTZ is a noncompetitive GABA receptor antagonist that produces generalized seizures at high doses. The forebrain is involved in the expression of clonic seizures, whereas the activation of brainstem structures participates in the expression of the tonic component (Yonekawa et al 1980). We found that there is an aggravation of PTZ-induced seizures following the repetitive administration of diazepam or vigabatrin. The shorter latency to all the components of the PTZ-induced seizures after subchronic administration with diazepam could result from a higher activation of forebrain areas, while the facilitation of the tonic extension component and mortality after subchronic treatment with vigabatrin could be restricted to an overactivation of brainstem areas. These results support previous studies indicating that the abrupt discontinuation of long-term use of BDZ may produce status epilepticus (Gatzonis et al 2000) and a higher seizure susceptibility to bicuculline (Gallager et al 1985). Regarding vigabatrin, its repetitive administration leads to decreased electroconvulsive threshold (Loscher 1982) and does not prevent the development of secondary spontaneous seizures as consequence of status epilepticus (Halonen et al 2001).

Diazepam produces its overt effects by interacting with a specific recognition site on $\mathrm{GABA}_{\mathrm{A}}$ receptors in the mammalian central nervous system. Diazepam enters brain rapidly, and is also cleared rapidly, yielding desmethyldiazepam and oxazepam as metabolites in 
plasma and brain (Greenblatt and Sethy 1990). However, the repetitive daily injection of diazepam is associated with a peak concentration at $2 \mathrm{~h}$ after injection and a progressive drug accumulation in brain (Fernandes et al 1999). This situation represents a marked fluctuation in receptor occupancy by diazepam over a 24 -h period that may induce a pharmacological kindling effect (Arnot et al 2001), a critical condition for the higher susceptibility to PTZ-induced seizures observed in the present study.

The reduction in the BDZ receptor binding detected after the subchronic administration with diazepam is in agreement with the results obtained from other authors in mouse brain (Rosenberg and Chiu 1979, 1981a, 1981b; Grimm and Hershkowitz 1981; Tietz et al 1986). Chronic treatment with diazepam has been shown to alter $\mathrm{GABA}_{\mathrm{A}}$ receptor affinity for the agonist GABA and some BDZ binding characteristics (Tietz et al 1989; Wu et al 1994). Indeed, repetitive daily injection of diazepam decreases GABA enhancement of BDZ binding (Arnot et al 2001). These receptor changes could be involved in the lower BDZ binding and the higher vulnerability to PTZ-induced convulsions detected after the repetitive administration with diazepam.

The pharmacodynamic effects of vigabatrin (inhibition of central and peripheral GABA-T and increase of brain GABA levels) remain after the drug has been eliminated from plasma (Bolton et al 1989). However, when treatment is continued for 8 days, more marked effects of vigabatrin on GABA-T and GABA, a more severe toxicity and higher vigabatrin plasma concentrations are observed (Valdizán and Armijo 1992; Valdizán et al 1999), and tolerance developed to the anticonvulsant effect of the treatment (Loscher and Frey 1987). We found that the subchronic administration of vigabatrin did not modify the $\left[{ }^{3} \mathrm{H}\right]$ flunitrazepam binding, a finding that is in agreement with others authors (Halonen et al 1991; Jackson et al 1994; Verhoeff et al 1999). Probably, the magnitude of the GABA level increase by vigabatrin is not sufficient to induce changes in the BDZ receptor (Maloteaux et al 1987). However, subcronic treatment with vigabatrin facilitated PTZ-induced seizures, an effect that could be explained by receptor desensitization or toxic effects. Indeed, in vigabatrin-treated animals, diazepam at high doses displayed lower anticonvulsant effects (Schmid et al 1996).

Gabapentin was originally developed as a chemical analogue of GABA. However, different mechanisms are known to be involved in different therapeutic actions of this drug (Cheng and Chiou 2006). Its mechanisms of action appear to be a complex synergy between increased GABA synthesis,
non-NMDA receptor antagonism and binding to the $\alpha 2 \delta$ subunit of voltage dependent calcium channels. The latter action inhibits the release of excitatory neurotransmitters (Bennett and Simpson 2004). Gabapentin fails to influence GABA concentrations following both single and repeated administration in mice (Leach et al 1997), but increases aminooxyacetic acid-induced GABA accumulation in several brain regions (Loscher et al 1991). The plasma gabapentin half-life after oral administration in rodents is only about $2 \mathrm{~h}$, and there is no evidence for accumulation of active metabolites (Vollmer et al 1986). Gabapentin exerts potent anticonvulsant effect in rats after $2 \mathrm{~h}$, but this effect is completely lost after $9 \mathrm{~h}$ (Loscher and Schmidt 1988). Our experiments revealed that subchronic administration with gabapentin did not modify the generalized seizures induced by PTZ, suggesting that its repetitive administration does not induce subsequent withdrawal-like effects.

It is known that the chronic exposition of an agonist produces an adaptation response that could be associated with receptor down-regulation or phosphorylation with a subsequent decrease in the response of involved system (Alberts et al 1994). These mechanisms could explain the decreased BDZ binding after the repetitive administration of antiepileptic drugs enhancing the GABAergic system. The differential effects on PTZ-induced seizures produced after subchronic diazepam, vigabatrin, and gabapentin may result from changes in specific subunits that regulate the $\mathrm{GABA}_{\mathrm{A}}$ or BDZ binding. For example, mutations in the $\gamma 2$ subunit may cause incorrect assembly of subunits with the receptor complex reducing sensitivity to BDZ, which would lead to an increase in neuronal excitability (Wu et al 2004). Similarly, deletion of $\mathrm{GABA}_{\mathrm{A}}$ receptor $\alpha 1$-subunit alters receptor subtype assembly, pharmacological and behavioral responses to BDZ (Kralic et al 2002). Concerning diazepam, its repetitive daily injection increases $\alpha 1$-subunit mRNA levels, an effect that may result in an increase in diazepam insensitive $\mathrm{GABA}_{\mathrm{A}}$ receptor subtypes (Arnot et al 2001). More experiments should be carried out to determine how the repetitive administration of antiepileptic drugs is associated with changes in $\mathrm{GABA}_{\mathrm{A}}$ receptor subunits leading to facilitation of seizure activity.

The mechanisms underlying the facilitation in seizure activity by antiepileptic drugs are poorly understood, but they may include the unmasking of secondary pharmacodynamic effects at high dosage or an undesired extension of the drug primary action to additional cell populations or neurotransmitters. Studies support the interactions between GABA and cannabinoid systems (Pertwee et al 1988; Warnault 
et al 2007). In fact, activation of presynaptic cannabinoid type 1 (CB1) receptors induces robust inhibition of local GABAergic afferents or depolarization-induced suppression of inhibition (DSI) (Wilson et al 2001; Wilson and Nicoll 2001). It is possible that the abrupt cessation of GABAergic drugs induces a withdrawal syndrome associated with sensitized GABAergic synapses to the presynaptic effect of cannabinoid $\mathrm{CB} 1$ receptor stimulation (Centonzene et al 2007). This situation may facilitate the DSI and the reduced threshold to the PTZ-induced seizures.

Our results provide evidence of a relationship between subchronic exposition of an antiepileptic drug and the decrease in the BDZ receptor binding, a phenomenon that could be involved in the mechanisms of pharmacoresistant epilepsy (Aicardi 1998; Jallon 1997; Loscher et al 1997).

\section{Acknowledgments}

The author thanks Magdalena Briones, Leticia Neri-Bazán and Héctor Vázquez for their excellent technical assistance. This study was partially supported by CONACyT grant 45943-M.

\section{References}

Aicardi J. 1988. Clinical approach to the management of intractable epilepsy. Dev Med Child Neurol, 30:429-40.

Alberts B, Bray D, Lewis J, et al. 1994. Molecular Biology of the Cell. New York; USA: Garland Publishing Inc., pp. 721-85.

Andrews N, Zharkovsky A, File SE. 1992. Acute handling stress downregulates benzodiazepine receptors: reversal by diazepam. Eur $J$ Pharmacol, 210:247-51.

Arnot MI, Davies M, Martin IL, et al. 2001. GABA(A) receptor gene expression in rat cortex: differential effects of two chronic diazepam treatment regimes. J Neurosci Res, 64:617-25.

Bennett MI, Simpson KH. 2004. Gabapentin in the treatment of neuropathic pain. Palliat Med, 18:5-11.

Bolton JB, Rimmer E, Williams J, et al. 1989. The effect of vigabatrin on brain and platelet GABA-transaminase activities. Br J Clin Pharmacol, 27(Supp11):35S-42S.

Braestrup C, Nielsen M, Squires RF. 1979. No change in rat benzodiazepine receptors after withdrawal from continuous treatment with lorazepam and diazepam. Life Sci, 24:347-50.

Brett RR, Pratt JA. 1995. Changes in benzodiazepine-GABA receptor coupling in an accumbens-habenula circuit after chronic diazepam treatment. Br J Pharmacol, 116:2375-84.

Calkin PA, Barnes EM. 1994. GABA Agonists down-regulate GABA Aben- $_{\mathrm{A}}$ zodiazepine receptor polypeptides from the surface of chick cortical neurons. J Biol Chem, 269:1548-53.

Centonze D, Rossi S, De Chiara V, et al. 2007. Chronic cocaine sensitizes striatal GABAergic synapses to the stimulation of cannabinoid CB1 receptors. Eur J Neurosci, 25:1631-40.

Cheng JK, Chiou LC. 2006. Mechanisms of the antinociceptive action of gabapentin. J Pharmacol Sci, 100:471-86.

Fernandes C, Arnot MI, Irvine EE, et al. 1999. The effect of treatment regimen on the development of tolerance to the sedative and anxiolytic effects of diazepam. Psychopharmacology (Berl), 145:251-9.

Gale K. 1992. GABA and epilepsy: basic concepts from preclinical research. Epilepsia, 33(Supp1 5): S3-S12.
Gallager DW, Lakoski JM, Gonsalves SF, et al. 1984. Chronic benzodiazepine treatment decreases postsynaptic GABA sensitivity. Nature, 308:74-7.

Gallager WD, Malcolm BA, Anderson AS, et al. 1985. Continuous release of diazepam: electrophysiological, biochemical and behavioral consequences. Brain Res, 342:26-36.

Gatzonis DS, Angelopoulos KE, Daskalopoulou GE, et al. 2000. Convulsive status epilepticus following abrupt high-dose benzodiazepine discontinuation. Drug Alcohol Depend, 59:95-7.

Greenblatt DJ, Sethy VH. 1990. Benzodiazepine concentrations in brain directly reflect receptor occupancy: studies of diazepam, lorazepam, and oxazepam. Psychopharmacology (Berl),102:373-8.

Grimm EV, Hershkowitz M. 1981. The effect of chronic diazepam treatment on discrimination performance and $3 \mathrm{H}$-flunitrazepam binding in the brains of shocked and nonshoked rats. Psychopharmacology, 74:132-6.

Gyenes M, Farrant M, Farb DH. 1988. "Run down" of GABA $A_{A}$ receptor function during whole-cell recording- a possible role for phosphorylation. Mol Pharmacol, 34:719-23.

Halonen T, Pitkanen A, Saano V, et al. 1991. Effects of vigabatrin (gamma-vynil GABA) on neurotransmission-related amino acids and on GABA and benzodiazepine receptor binding in rats. Epilepsia, 32:242-9.

Halonen T, Nissinen J, Pitkanen A. 2001. Chronic elevation of brain GABA levels beginning two days after status epilepticus does not prevent epileptogenesis in rats. Neuropharmacol, 40:536-50.

Haefely W, Kyburz E, Gerecke M, et al. 1995. Recent advances in the molecular pharmacology of benzodiazepine receptors and in the structure-activity relationship of their agonist and antagonist. $A d v$ Drug Res, 14:165-322.

Jackson FM, Dennis T, Esplin B, et al. 1994. Acute effects of gamma-vynil GABA (vigabatrin) on hippocampal GABAergic inhibition in vitro. Brain Res, 651:85-91.

Jallon P. 1997. The problem of intractability: the continuing need for new medical therapies in epilepsy. Epilepsia, 38(Suppl 9)S37-S42.

Kralic JE, O'Buckley TK, Khisti RT, et al. 2002. GABA(A) receptor alpha-1 subunit deletion alters receptor subtype assembly, pharmacological and behavioral responses to benzodiazepines and zolpidem. Neuropharmacology, 43:685-94.

Leach JP, Sills GJ, Butler E, et al. 1997. Neurochemical actions of gabapentin in mouse brain. Epilepsy Res, 27:175-80.

Lippert B, Metcalf B, Jung MJ, et al. 1977. 4-amino- hex-5-enoic acid, a selective catalytic inhibitor of 4- aminobutyric acid aminotransferase in mammalian brain. Eur J Biochem, 74:441-5.

Loiseau P. 1998. Do antiepileptic drugs exacerbate seizures? Epilepsia, 39:2-4.

Loscher W. 1982. Anticonvulsant and biochemical effects of inhibitors of GABA amitransferase and valproic acid during subchronic treatment in mice. Biochem Pharmacol, 31:837-42.

Loscher W, Hönack D, Taylor CP. 1991. Gabapentin increases aminooxyacetic acid-induced GABA accumulation in several regions of rat brain. Neurosci Lett, 128:150-4.

Loscher W. 1997. Animal models of intractable epilepsy. Prog Neurobiol, 53:239-58.

Loscher W, Frey HH. 1987. One to three day dose intervals during subchronic treatment of epileptic gerbils with gamma-vinyl GABA: anticonvulsant efficacy and alterations in regional brain GABA levels. Eur J Pharmacol, 143:335-42.

Loscher W, Schmidt D. 1988. Which animal models should be used in the search for new antiepileptic drugs? A proposal based on experimental and clinical considerations. Epilepsy Res, 2:145-81.

Lukas SE, Griffith RR. 1984. Precipitated diazepam withdrawal in baboons: effects of dose and duration of diazepam exposure. Eur J Pharmacol, 100:163-71.

Maloteaux JM, Octave JN, Gossuin A, et al. 1987. GABA induces downregulation of the benzodiazepine-GABA receptor complex in the rat cultured neurons. Eur J Pharmacol, 144:173-83. 
Olsen WR, Avoli M. 1997. GABA and epileptogenesis. Epilepsia, 38:399-407.

Perucca E, Gram L, Avanzini G, et al. 1998. Antiepileptic drugs as a cause of worsening seizures. Epilepsia, 39:5-17.

Pertwee RG, Greentree SG, Swift PA. 1988. Drugs which stimulate or facilitate central GABAergic transmission interact synergistically with delta-9-tetrahydrocannabinol to produce marked catalepsy in mice. Neuropharmacology, 27:1265-70.

Rosenberg CH, Chiu HT. 1979. Decreased 3H-diazepam binding is a specific response to chronic benzodiazepine treatment. Life Sci, 24:803-8.

Rosenberg CH, Chiu HT. 1981a. Tolerance during chronic benzodiazepine treatment associated with decreased receptor binding. Eur J Pharmacol, $70: 453-60$.

Rosenberg CH, Chiu HT. 1981b. Regional specificity of benzodiazepine receptor down-regulation during chronic treatment of rats with flurazepam. Neurosci Lett, 24:49-52.

Schechter PJ, Tranier Y, Grove J. 1979. Attempts to correlate alterations in brain GABA metabolism by GABA-T inhibitors with their anticonvulsant effects. In: Mandel P, DeFeudes FV (eds). GABA- biochemistry and CNS functions. New York: Plenum Pr, pp. 43-57.

Schmid L, Bottlaender M, Brouillet E, et al. 1996. Vigabatrin modulates benzodiazepine receptor activity in vivo: a positron emission tomography study in baboon. J Pharmacol Exp Ther, 276:977-83.

Suman-Chauhan N, Webdale L, Hill DR, et al. 1993. Characterization of ${ }^{3} \mathrm{H}$-gabapentin binding to a novel site in rat brain: homogenate binding studies. Eur J Pharmacol, 244:293-301.

Taylor PC, Gee SN, Su TZ, et al. 1998. A summary of mechanistic hypotheses of gabapentin pharmacology. Epilepsy Res, 29:233-49.

Tietz IE, Rosenberg CH, Chiu HT. 1986. Autoradiographic localization of benzodiazepine receptor downregulation. J Pharmacol Exp Ther, 236:284-92.

Tietz EI, Chiu TH, Rosenberg HC. 1989. Regional GABA/benzodiazepine receptor/chloride channel coupling after acute and chronic benzodiazepine treatment. Eur J Pharmacol, 167:57-65.

Valdizán EM, Armijo JA. 1992. Effects of single and multiple increasing doses of vigabatrin on brain GABA metabolism and correlation with vigabatrin plasma concentration. Biochem. Pharmacol, 28:2143-50.
Valdizán EM, García AP, Armijo JA. 1999. Time course of the GABAergic effects of vigabatrin: is the time course of brain GABA related to platelet GABA-transaminase inhibition? Epilepsia, 40:1062-9.

Verhoeff GLPN, Petroff CAO, Hyder F, et al. 1999. Effects of vigabatrin on the GABAergic system as determined by 123I-Iomazenil SPECT and GABA MRS. Epilepsia, 40:1433-8.

Vollmer KO, von Hodenberg A, Kölle EU. 1986. Pharmacokinetics and metabolism of gabapentin in rat, dog and man. Arzneimittelforschung, 36:830-9.

Warnault V, Houchi H, Barbier E, et al. 2007. The lack of CB1 receptors prevents neuroadapatations of both NMDA and GABA(A) receptors after chronic ethanol exposure. J Neurochem, 102:741-52.

Williams RW, Williams AG, Capra T. 1999. Atlas of the mouse brain [online]. Accessed on November 12, 2007. URL: http://www.mbl. org/atlas/atlas.php.

Wilson RI, Kunos G, Nicoll RA. 2001. Presynaptic specificity of endocannabinoid signaling in the hippocampus. Neuron, 31:453-62.

Wilson RI, Nicoll RA. 2001. Endogenous cannabinoids mediate retrograde signalling at hippocampal synapses. Nature, 410:588-92.

Wu Y, Rosenberg HC, Chiu TH, Ramsey-Williams V. 1994. Regional changes in [3H]zolpidem binding to brain benzodiazepine receptors in flurazepam tolerant rat: comparison with changes in [3H]flunitrazepam binding. J Pharmacol Exp Ther, 268:675-82,

Wu J, Ellsworth K, Ellsworth M, et al. 2004. Abnormal benzodiazepine and zinc modulation of GABAA receptors in an acquired absence epilepsy model. Brain Res, 1013:230-40.

Yonekawa WD, Kupferberg HJ, Woodbury DM. 1980. Relation between pentylenetetrazol-induced seizures and brain pentylenetetrazol levels in mice. J Pharmacol Exp Ther, 214:589-93.

Yu R, Ticku MK. 1995. Chronic neurosteroid treatment produces functional heterologous uncoupling at the $\mathrm{GABA}_{\mathrm{A}}$ /benzodiazepine receptor complex in mammalian cortical neurons. Mol Pharmacol, 47:603-10. 
